\title{
A FOLYAMATOS DIFFERENCIÁLT FOGLALKOZTATÁS HATÁSA A KÖZÖSSÉG IRÁNTI BEÁLLÍTÓDÁS ALAKULÁSÁRA FELSŐ TAGOZATOS TANULÓKNÁL
}

\section{Szerzők:}

Kós Nóra

Gál Ferenc Főiskola

Szabóné Balogh Ágota

Gál Ferenc Föiskola

Lestyán Erzsébet

Gál Ferenc Föiskola

Harsányiné Petneházi Ágnes

Nyíregyházi Egyetem

Első szerző e-mail címe:

kosnora@gmail.com

\section{Lektorok:}

Fest Sarolta

Gál Ferenc Főiskola

Katona Krisztina

Gál Ferenc Főiskola

Mező Ferenc

Eszterházy Károly Egyetem

Nemes Magdolna

Debreceni Egyetem

Kós Nóra, Szabóné Balogh Ágota, Lestyán Erzsébet, Harsányiné Petneházi Ágnes (2017): A folyamatos differenciált foglalkoztatás hatása a közösség iránti beállítódás alakulására felső tagozatos tanulóknál. Különleges Bánásmód, III. évf. 2017/1. szám, 7-25. DOI 10.18458/KB.2017.3.7

\begin{abstract}
Absztrakt
Háttér és célkitüzés: Longitudinális kutatás (2006-2010) során a felső tagozatos tanulók önértékelésének, énképének, közösség iránti beállítódásának és szorongás szintjének változását vizsgáltuk. Célunk kideríteni, hogy mennyire befolyásolja a gondosan megtervezett és folyamatos differenciált foglalkoztatás a tanulók előbb említett jellemzőit. Jelen tanulmányban a közösség iránti beállítódás alakulása kerül bemutatásra. Módszer: A közösség iránti beállítódás mérése a Hunyadyné által kidolgozott (1977), Tóth által módosított mérőeszközzel (2005) (1. melléklet). Hipotézis: Feltételezés szerint a felső tagozatos tanulók közösségi iránti beállítódásának a fejlődése a folyamatos differenciálás hatására a kísérleti csoportnál hamarabb indul meg, és ez hatékonyabb lesz, mint a kontrollcsoportnál. Eredmények: A kísérleti csoportban a közösség iránti beállítódás területei általában nagyobb fejlődést mutattak, mint annál a csoportnál, ahol differenciált fejlesztést csak elvétve végeztek. Szignifikáns eltérések tapasztalhatók a tágabb közösséghez füződő viszony, a közösségi tevékenység és az osztálykohézió fejlődése területein. Következtetések: Az eredmények igazolják, hogy a megfelelö differenciált fejlesztés előnyös a közösség iránti beállítódás területeire nézve.
\end{abstract}

Kulcsszavak: differenciált oktatás, társas kapcsolatok, közösség, társas összehasonlítás

Diszciplína: pedagógia, pszichológia 


\begin{abstract}
Background and objectives: In a longitudinal research (2006-2010) we examined the progression of upper elementary school students' self-assessment, self-image, attitude toward community and change in their anxiety level in order to find out to what degree carefully planned and continuously differentiated education influence these traits of students' behaviour. In this present study we address the change in their attitude toward community. Method: We used the measurement tool developed by Hunyadyné and modified by Tóth for measuring the attitude toward community (Appendix 1). Hypothesis: We assumed that as a result of differentiation the upper elementary school students' attitude toward community will progress earlier and more effectrively in the pilot than the control group (school community, the society; the class' cohesion force, self-government's role and competence, function of public opinion, potential sociometric relation within the class, group activities). Results: The controlled and planned differentiated development made the areas of attitude toward community advance more in the pilot group than in the group going under only scarce differentiated development. We experienced significant difference in the scales of relation to the broader community, group activity and class cohesion. Conclusions: Results justify that appropriate differentiated development has got advantageous impact on attitude toward community.
\end{abstract}

Keywords: social relation, differentiated education, social comparison

Disciplines: pedagogy, psychology

A differenciálás történeti gyökerei a XIX. század végére és a XX. század elején kibontakozó reformpedagógiai törekvésekhez kapcsolható. Ebben az időszakban kiemelkedő figyelmet kap a gyermekkor pedagógiai és pszichológiai értelmezése, megfigyelése. A gyermekközpontúságot mutatja és hirdeti Montessori Mária pedagógiája, Rudolf Steiner alapította Waldorf iskola nézetei vagy éppen Peter Peterson által létrehozott Jéna-terv (Polonkai, 2002).

A neveléstörténeti kutatások, megfigyelések és leírások rámutatnak arra, hogy a differenciálás alkalmazása nélkülözhetetlen a pedagógiai munkában. A mindennapi tanítási folyamat szerves részévé kell, hogy váljon a differenciálás a tanulók és az oktatás színvonalának érdekében. Hazánkban már az 1993-ban elfogadott közoktatási törvény (1996ban, majd 1999-ben módosították) kiemeli, hogy a tanulóknak joga van adottságának, képességének és érdeklődésének megfelelő oktatásban részesülnie.

„Azt a pedagógiai funkciót, amely a tanulással kapcsolatos egyéni és a csoportkülönbségek figyelembevételét írja elő a tanítási-tanulási folyamat minden mozzanatára nézve, differenciálásnak nevezzük.” (Báthory, 1985. pp. 70.). A pedagógusok differenciálásról alkotott képe egyre inkább formálódik az ismeretek és a gyakorlati tapasztalatok hatására. Ezt mutatja Petriné és munkatársai (2001) újabb kutatása. Más kutatások is kimutatták (Eyre \& Fuller, 1993) hogy a tanárok többet szeretnének foglalkozni az egyéni képességekkel, de nagyon sok idő elmegy az óraszervezési feladatokra, ami nehezíti a differenciálást.

A pedagógusok hozzáállása mellett meghatározó a tanulók tanulási teljesítményében a környezet, a társas kapcsolatok és az érzelem. Az erre vonatkozó nemzetközi vizsgálatok információkat gyüjtöttek a tanulók attitüdjéről, a tanításról alkotott véleményről, a tantermi tartalomról és az iskolai-, valamint az osztálykörnyezetről a metakognitív folyamataik megértésén és értelmezésén keresztül. A program során kiemelt terület volt a reflektáló tevékenység, a motiváció, a stratégiahasználat, valamint az emlékezés, a leleményesség és a 
reflektivitás (Wall, 2008). Továbbá a kutatások alátámasztják, hogy az érzelmek, ahogyan a tanuló érzi, magát az iskolában, erőteljesen befolyásolja a kognitív fejlődést és a tanulást (Dai \& Sternberg, 2004; Schutz \& Pekrun, 2007).

Jelen kutatásunkban a differenciált oktatás hatásait kívántuk vizsgálni, de nem a tanulmányi eredményesség oldaláról, hanem annak pszichológiai hatását próbáltuk megragadni, egészen pontosan azt, milyen hatást gyakorol a differenciált oktatás bizonyos személyiségváltozókra (önértékelés, énkép, közösség iránti beállítódás és a szorongás). E tanulmányban azt mutatjuk be, hogy mennyire meghatározó a differenciált fejlesztés a közösség iránti beállítódás területeit nézve. A kutatás longitudinális jellegü volt, ugyanazokat a tanulókat követtük nyomon, négy éven át az általános iskola ötödik osztályától a nyolcadik osztályáig (a bemenettől a kimenetig). Számolva a fluktuációval, csak azoknak a tanulóknak az eredményei kerültek végső rögzítésre az adatbázisban, akik az elejétől a végéig az összes felmérésben részt vettek.

A tanulmány első részében a társas kapcsolatok elméleti megközelítéseit ismertetjük, a második felében a közösség iránti beállítódást vizsgáló kérdőívvel nyert mérési eredményeket mutatjuk be.

\section{A 10-14 ÉVES KORÚ GYERMEKEK JELLEMZÖI}

Az általunk vizsgált korcsoport 10-től 14 éves korig magába foglalja a kisiskoláskor végét és a serdülőkor elejét. Ebben az átmeneti időben a gyermekek életében a biológia és társas vonatkozások újjászerveződnek. A testi fejlődés mellett a családdal és a kortársakkal való kapcsolatban is változások jönnek létre (Cole, 2002). Emellett változások tapasztalhatók az iskolai teljesítményben is. Ebben az időszakban egyre inkább észrevehető a tanulás iránti motiváció csökkenése. Wedder-Weiss és Fortus (2012) kutatása szerint az európai kultúrkörre általánosan jellemző jelenségről van szó, mert mindegyik általuk vizsgált európai országban egységesen a tanulási motiváció csökkenését találták.

\section{A társas kapcsolatok változásai}

A 10-14 éves korban a társak fontossága kiemelkedik, és megjelenik a másik nem iránti érdeklődés. Ezt figyelembe véve Vekerdy Tamás ezt az időszakot a „második születés” korának nevezi: „Amikor egy elkülönült személyiség szakad ki a család érzelmi burkából úgy, hogy a világgal, önmagával egyedül szembenézzen. Mint a biológiai születés, ez is fájdalmakat okoz nekünk, ......, de ő maga is szenved." (idézi Kulcsár, 2004. pp. 9.)

A gyermekek kortársaihoz füződő viszonya a serdülőkor végéig folyamatosan változik. Míg kezdetben a közös időtöltés, azonos játék, hobbi határozza meg a baráti kapcsolatok létrejöttét, később a szimpátia és a belső tulajdonságok a döntőek (Kollár \& Szabó, 2004). Ezek a baráti társaságok lehetőséget biztosítanak arra, hogy kialakuljanak a csoportbeli szerepek, és az önmagát kereső serdülő énképe, önismerete formálódjon.

Kisiskoláskortól kezdve látványosan fejlődik a tanulók szociális kompetenciája. Ezt meghatározza az érzelmi élet fejlődése, az én fejlődése, az értelmi funkciók érése, másrészt az iskolai és iskolán kívüli társas kapcsolatok. Vajda (2002) véleménye szerint az iskolás gyermekek egyre inkább eredményesebbek lesznek a beszélgetéseikben, az együttes tevékenységeikben, kialakulnak a barátságok, hiszen fejlödik a személyészlelésük és a kommunikációjuk. Egyre inkább megerősödnek az osztályon belüli csoportok. Good és Brophy (2008) munkájukban összegzik, hogy a tanulói csoportképzés, szelekció hogyan hat a tanulási énképre.

Nem feledkezhetünk meg arról sem, hogy a kortársi kapcsolatok mellett a megfelelő családi kapcsolatok, a bizalom, a családban elfoglalt hely, a szeretet is meghatározza a gyermek pozitív irányú fejlődését. A család, mint elsődleges szocializációs tér alapozza meg a másokkal való érzelmi kapcsolat kialakításának és fenntartásának tanult elemeit (Zsolnai, 
2003). A családi háttér és a tanulók sikeressége között szoros kapcsolat van (Csapó, 2003; Józsa, 2004). A család és az iskola, az osztályközösség egyaránt meghatározó az egyén szocializációjában. Az iskolai osztályoknak is meghatározó szerepe van a valahová tartozás, az elfogadás érzésének kialakításában.

Nagy és Zsolnai (2001) kutatásai mutatják, hogy a szociális kompetencia fejlődése a szabadságfok növekedésével (az öröklött és a tanult tényezők hierarchizálódásával) és a proszocialitás erősödésével (a mások érdekeinek figyelembe vétele) érhető el. Ennek értelmében az öröklött elemek kiegészülnek a tanult elemekkel. Ezek a tanult elemek a társas közeggel való folyamatos kapcsolatban fejlödnek. Ezt a kutatási eredményt is figyelembe véve arra a következtetésre jutottunk, hogy a folyamatos tudatos differenciált fejlesztés pozitívan befolyásolhatja a tanulók társas közeghez való viszonyát (Nagy \& Zsolnai, 2001).

A társaik és a csoportban elfoglalt hely segítségével folyamatosan kezdik megismerni önmagukat (Murányi-Kovács, 1980). Hattie (2008) megfigyelései azt mutatják, hogy a diákok magukkal kapcsolatos értékelése a leginkább meghatározó tényező az iskolai teljesítményben.

\section{A kortársak szerepe a fejlődésben}

A kortársak szerepe, véleménye egyre inkább erősödik, és meghatározó szerepet tölt be a személyiség fejlődésében, a tanuló iskolai teljesítményében (Cole, 2002). Marsh és Craven (2002) kutatásai azt mutatják, hogy az iskolai énképet nagymértékben befolyásolja az iskola, az osztály, az osztályon belüli tanulók teljesítménye és képessége. A diákok közérzete összefügg az iskolával és annak társas jellemzőivel való elégedettséggel. Az iskolai légkör pozitív megélése (befogadó társas légkör, segítőkész osztálytársak), a sikeres alkalmazkodás (magasabb iskolai teljesítmény, feladatok végrehajtásával járó kevesebb stressz) magasabb önértékelést, az élettel való elégedettséget eredményez (Currie és mtsai, 2012).

Hazai kutatások összegzik, hogy a tanulmányi eredmény 3. és 7. évfolyamon összefüggést mutat azzal, hogy a tanulók baráti kapcsolatban vannak-e az osztálytársaikkal. Megfigyelhetővé válnak a különböző iskolatípusok közötti eltérések, melyekben meghatározó az osztálykohézió kialakításának szokásai (Mártonné és Kollár, 2001).

Mikulas és Vodanovich (1993) arról számolnak be, hogy az érzelmek befolyásolják a teljesítményt. Emellett a tanulói célorientációktól függetlenül az iskolai és az osztálytermi célstruktúrák szintén hatást gyakorolnak a teljesítményre (Linnenbrink, 2004; Murayama \& Elliot, 2009). A kutatások eredményeit figyelembe véve létfontosságú a tervezett és a tudatos differenciálás megfelelő alkalmazása a tanítás folyamatában.

Kutatásunkban azért is emeltük ki a társas kapcsolatok fejlődését, mivel a HBSC-mérések eredményei azt mutatják, hogy a 2002-2006 közötti időszakban az osztályközösségről és a társakról kialakított vélemény negatív irányú változást mutat. Az Egészségügyi Világszervezet (World Health Organisation, WHO) által készített HBSC-felméréssorozat (Health Behaviour in School-aged Children) az 5-12. évfolyamos tanulók részvételével készült (Németh \& Költő, 2011). Az eredmények összegzésekor azt tapasztalták, hogy a diákok „szubjektív jólléte” összefügg az iskolai teljesítménnyel és az iskolához való viszonnyal (Józsa és Fejes, 2012).

A társas közegben a másokkal való összehasonlítás és versengés alapvető kritériuma az önismeret, az önértékelés és az énkép fejlődésének, ennek biztosít teret az iskola, ahol az önismeret fejlődésével párhuzamosan a tanulók megismerik saját képességeiket, értékeiket (Festinger, 1976). A társas összehasonlítás három funkcióját a 1. ábra mutatja. 
1. ábra. A társas összehasonlítás funkciói (Forrás: a Szerzök Festinger 1976 tanulmánya alapján)

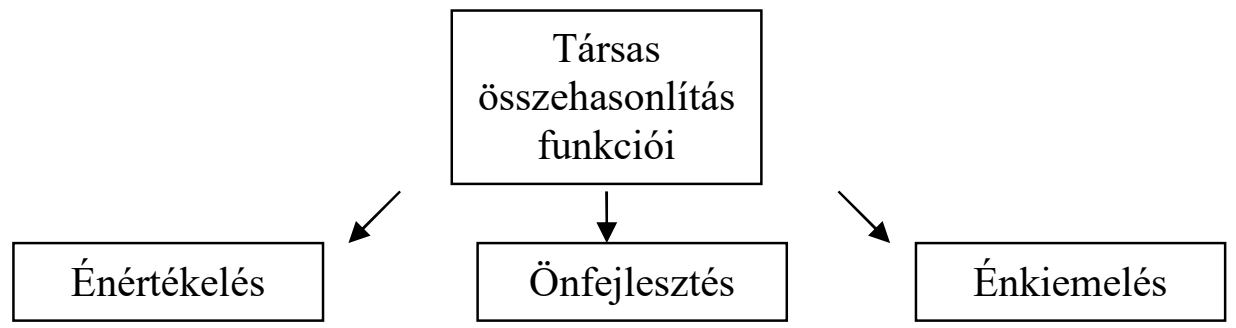

A társas összehasonlítás legfontosabb feladata, az énértékelés, hiszen ez teszi lehetővé, hogy megismerjük személyiségünket, képességeinket és lehetőségeinket. Három szakaszból áll.

- önmagunk megítélése a másokkal való összehasonlítás, mások tevékenységének megfigyelése során,

- önmagunk értékelése, saját képességeink és gyengeségeink felismerése során,

- motivációs szakasz, az előbbiekből levont következtetések motiválják a teljesítményt (Fülöp, 2000).

Az önfejlesztés egy hosszabb folyamat a személyiségfejlődésben, de az egész életet végigkíséri. Az egyik jellemzője a felfele hasonlítás, mely során olyan egyénnel hasonlítjuk össze önmagunkat, aki bizonyos területeken jobb eredményeket ér el, mint mi.

Az énkiemelést azonban a lefele hasonlítás jellemzi, amely alapvetően akkor lép fel, amikor az egyén önértékelése veszélybe kerül, és szükség van az azonnali pozitív megerösítésre (Fülöp, 1995).

Rheinberg, német pszichológus (1999) az összehasonlítás szerepének bemutatására bevezette a tanári viszonyítása alap fogalmát. A tanár által alkalmazott viszonyítási alapot normaként határozta meg, mellyel összeveti az egyéni teljesítményt. Az egyéni teljesítményt összeveti a korábbi teljesítménnyel, ekkor egyéni viszonyítási alapról beszélünk. Amikor tanulók teljesítményét hasonlítja össze az osztálytársak teljesítményével, akkor társas viszonyítási alapról beszélünk. A megfigyeléseikben azt összegezték, hogy az egyéni megközelítés következménye, hogy a tanulók közvetlenül érzékelik teljesítményük javulását, ami pozitívan hat az énkép fejlődésére.

A szociálpszichológia kezdeti kutatásai is azt mutatták, hogy a társak jelenléte növeli a teljesítményt (Triplett, 1987). A tanulás folyamatában meghatározó szerepe van a társaknak, osztálytársaknak, melynek alapját a többiek teljesítményének elérése, túlszárnyalása és a többiek szociális elismerése adja. A másik eredményeinek elérése vagy túlteljesítése során érzett öröm attól függ, hogy mennyivel teljesít jobban a többi diáknál (Hidi \& Harackiewicz, 2000). A gyermekek együttmüködése, egymás munkájának elismerése pozitívan hat a teljesítményre, motiválja a tanulókat (Józsa \& Székely, 2004).

A differenciálás feladata, hogy figyelembe vegye az egyéni képességeket, ennek megfelelően segítse a tanulók fejlődését. Ezt erősítik John Hattie (2008) megfigyelései, aki összefoglalja azokat a tényezőket, amelyek befolyásolják az iskolai eredményességet. Azt tapasztalta, hogy az osztály kohéziója, az irányítása és a viselkedése egymással összefüggésben gátolja, vagy elősegíti az iskolai teljesítményt. A tanárok és diákok sikeres együttműködése meghatározza az osztálykohézió erejét, a társas támogatás optimalizálhatja az osztály légkörét. 
Benda József (2002), a kooperatív oktatás hazai úttöröje követéses vizsgálatban bizonyította, hogy a kölcsönösen elfogadó és támogató légkör pozitívan hat az önbecsülésre, az önkontrollra és az iskolai teljesítményre. Ebben a megfigyelésben nem voltak kirekesztett tanulók, baráti párok, a szociometriai vizsgálatok azt mutatták, hogy az osztályt a pozitív kapcsolatok jellemezték.

A fentiek részletezését azért tartottuk fontosnak, mert a longitudinális kutatásunk a közösség iránti beállítódás feltárását célozta meg annak kiderítésére, hogy a differenciálás hogyan befolyásolja ennek alakulását, személyiségfejlesztési szempontból előnyös-e a differenciált fejlesztés. Mivel a Hunyadyné-féle, Tóth által módosított mérőeszköz alkalmasnak tünt a társas kapcsolatok különböző területeinek megragadására, ezért esett választásunk erre a módszerre.

A teljesség kedvéért megemlítjük, hogy a nemzetközi szakirodalomban egyetlen ehhez hasonló módszert találtunk. Ez a SAGE (Student Attitudes toward Group Environments). A cikk szerzői (Kouros és Abrami, 2006) annyira egyedülállónak tartják saját kérdőívüket, hogy állításuk szerint nincs más ilyen jellegű kérdőív. Számunkra ez azonban nem volt használható, mivel: 1) középiskolások és egyetemisták vizsgálatához készült, 2) az 59 kérdésből sok csak az adott kultúrkörben (Kanada) értelmezhető, 3) a kérdések ömlesztettek, nincsenek kategóriákba gyüjtve.

\section{A KUTATÁS BEMUTATÁSA}

\section{Vizsgálati módszer és eszköz}

Jelen kutatási beszámoló részét képezi egy nagyobb ívű vizsgálatsorozatnak, melynek célja annak kiderítése, hogy a folyamatos differenciált fejlesztés mennyiben elönyös különböző személyiségjellemzőkre nézve. Ebben a beszámolóban a közösség iránti beállítódás vizsgálatát mutatjuk be.

A pedagógiában és a pszichológiában számos olyan kutatás készült az évtizedek alatt, melyek vizsgálják a csoport szerkezetét (szociometria) és a társak egymáshoz való viszonyát. Erre lehetőséget adnak a következő pedagógiában használható módszerek:

- komplex helyzetelemzés a tanulócsoportban,

- megfigyelés,

- eseménynapló készítése,

- időmérleg (a tanulóról, a család életről és a pedagógusról ad információt),

- dokumentumelemzés (Szekszárdi, 1992).

A kutatásunkban választott vizsgálati módszer a közösség iránti beállítódás mérésére: Hunyadyné-féle, Tóth által módosított mérőeszköz a közösség iránti beállítódás vizsgálatára (1. melléklet). Ez a skála lehetőséget biztosít a társas kapcsolatokhoz, tágabb közösségekhez való beállítódás mérésére. Az itemek több területre vonatkoznak:

- az iskolaközösség, a társadalom,

- az osztály kohéziós ereje,

- az önkormányzat szerepe és jogköre,

- a közvélemény funkciója,

- az osztályon belüli lehetséges szociometrikus kapcsolat,

- a közösségi tevékenységek.

Hunyadyné (1977) eredeti vizsgálatában 48 item szerepel, de a kutatásban a 40 itemből álló skálát alkalmaztuk. A skála állításai három csoportba bonthatóak:

- a pozitív állítások (13 tétel), elérhető pontszám: 65 ,

- a negatív állítások (20 tétel), elérhető pontszám: 100,

- a túlzó állítások (7 tétel), elérhető pontszám: 35. 
A tanulók valamennyi itemnél 1-től (teljes egyet nem értés) 5-ig (teljes egyetértés) terjedő skálán értékelhetnek. Az elérhető maximális pontszámok alapján értékelhető a kérdőív (Tóth, 2005).

\section{Minta és eljárás}

A két vizsgálati csoport (kísérleti és kontrollcsoport) kiválasztása teljesen véletlenszerü volt. Arra törekedtünk, hogy az ország különböző kis és nagyobb városaiban legyenek kísérleti és kontrollosztályok egyaránt. (Kísérleti csoport: Dombrád, Mátészalka, Nagyszénás, Szolnok, Hajdúböszörmény, Szarvas, Szeghalom. Kontrollcsoport: Szentes, Békéscsaba, Komádi, Paks, Mezőkovácsháza, Nyírbátor.) A pszichológiai kérdőívek felvétele az adott általános iskolában osztálytermi keretek között történt részben általunk, részben pedagógusok közremüködésével. A tesztek kitöltése az első évben két alkalommal, majd a további években egy alkalommal történt. A kérdőívek felvételénél figyelembe kellett venni a tanulók figyelmét és terhelhetőségét (első alkalom: énkép és közösség iránti beállítódás teszt, második alkalom: szorongás és önértékelés kérdőív). A kutatás során fontosnak tartottuk, hogy olyan vizsgálati módszereket válasszunk, amelyek alkalmasak arra, hogy az ötödikes tanuló és a nyolcadikos tanuló személyiségjegyeit is megfelelően mérje. A vizsgálatok megkezdése előtt a szülök egy tájékoztatón vettek részt, majd ezt követően írásbeli hozzájárulásukat kértük a tesztek felvételhez.

Mint korábban említettük, a kísérleti csoportban folyamatos tervezett és tudatos differenciált fejlesztés folyt három tantárgynál (a magyar, a matematika és a történelem minden óráján) négy éven keresztül, míg a kontrollcsoportban differenciálásra csak alkalomszerüen került sor.

Az általunk véletlenszerüen kiválasztott kísérleti iskolák pedagógusai vállalták, hogy a négy év kutatása során, az ötödiktől a nyolcadik osztályig három tantárgyon belül elöre kidolgozott óravázlat felhasználásával tartják meg a tantárgyi óráikat.

A differenciált fejlesztéshez az oktatócsomagokat a Szent István Egyetem Pedagógiai Kara, Szarvas tantárgy-pedagógiai csoportjai készítették havi bontásban. A magyar nyelv, a matematika és a történelem tantárgyhoz kapcsolódtak a tudatos differenciálást biztosító feladatok, gyakorlatok. A kísérletben oktató pedagógusokkal való egyeztetést követően minden hónap elején megkapták a heti óravázlatokat, melynek segítségével végezték a differenciálást. A program biztosította számukra, hogy az átlagos képességű és az átlagtól eltérő képességü tanulók fejlődését is megvalósíthassák az órákon. Az órákról a pedagógusoktól és a tanulóktól is folyamatosan pozitív visszajelzést kaptunk. Az esetleg felmerülő hibákat hónapról hónapra tudtuk javítani, hiszen rendszeres volt a kapcsolattartás.

Szeretnénk kiemelni, hogy míg a négy év során a kísérleti csoportok részesültek a programcsomagban, addig a kontrollcsoportok iskolái semmilyen programcsomagot nem kaptak. Pontosan erre épült kutatásunk, ugyanis a hipotézisekben megfogalmazott eredményekre voltunk kíváncsiak, miszerint a tudatos, tervezett, folyamatos differenciálás pozitívan hat a tanulók személyiségjegyeinek fejlődésére.

A vizsgált életkor: 10-14 éves tanulók (5-6-7-8. évfolyam longitudinális vizsgálata)

Mérések száma: 5. évfolyam év elején és végén, 6. 7. 8. évfolyam egy mérés történt a kísérleti és a kontrollcsoportokban is.

Résztvevők, létszám: Csak azoknak a tanulóknak az adatait dolgoztuk fel, akik az összes mérésben részt vettek. Az 1. táblázat ezt tükrözi. 
1. táblázat. Résztvevők, létszám

\begin{tabular}{|l|c|c|c|}
\cline { 2 - 4 } \multicolumn{1}{c|}{} & Fiú & Lány & Összesen \\
\hline Kísérleti csoport & 86 & 91 & 177 \\
\hline Kontrollcsoport & 83 & 94 & 177 \\
\hline
\end{tabular}

A kutatás a 2006/2007-es tanévben kezdődött és a 2009/2010-es tanévben fejeződött be. A négy évig tartó, a felső tagozat teljes időtartamára kiterjedő kutatás keretében kísérleti és kontrollcsoportok alkalmazásával kívántuk igazolni azt a feltételezést, hogy a differenciált fejlesztésben részesülő tanulók (kísérleti csoport) bizonyos személyiségjellemzőinek változása nagyobb mértékü, mint a differenciált fejlesztésben nem részesülő tanulók (kontrollcsoport) ugyanezen jellemzőinek változása. A következőkben a négy éves kutatás eredményeit mutatjuk be a közösség iránti beállítódás vonatkozásában.

\section{Vizsgálati eredmények}

A leíró statisztikai eredményei (átlag, szórás) láthatóak a 2. és a 3. táblázatban, illetve a bemeneti és a kimeneti mérések közötti átlagok különbsége.

2. táblázat. A közösség iránti beállitódás átlagai és szórásai a kísérleti csoportban (Forrás: a Szerzö)

\begin{tabular}{|c|c|c|c|c|c|c|c|c|c|c|c|c|}
\hline \multirow{2}{*}{\multicolumn{2}{|c|}{$\begin{array}{l}\text { Közösség iránti } \\
\text { beállítódás } \\
\text { Kísérleti csoport } \\
\mathrm{N}=177 \\
\text { Fiú: } 86 \text {, Lány: } 91\end{array}$}} & \multicolumn{2}{|c|}{$\begin{array}{c}\text { 1.mérés } \\
\text { (bemenet) }\end{array}$} & \multicolumn{2}{|c|}{ 2. mérés } & \multicolumn{2}{|c|}{ 3. mérés } & \multicolumn{2}{|c|}{ 4. mérés } & \multicolumn{2}{|c|}{$\begin{array}{l}\text { 5. mérés } \\
\text { (kimenet) }\end{array}$} & \multirow{2}{*}{$\begin{array}{l}\text { átlagok } \\
\text { különb- } \\
\text { sége } \\
\text { beme- } \\
\text { net és } \\
\text { kimenet }\end{array}$} \\
\hline & & \multirow{2}{*}{\begin{tabular}{r|} 
átlag \\
9,36
\end{tabular}} & \multirow{2}{*}{\begin{tabular}{r|} 
szórás \\
1,999
\end{tabular}} & \multirow{2}{*}{$\begin{array}{r}\text { átlag } \\
9,86\end{array}$} & \multirow{2}{*}{\begin{tabular}{r|} 
szórás \\
1,965
\end{tabular}} & \multirow{2}{*}{$\frac{\text { átlag }}{10,69}$} & \multirow{2}{*}{$\begin{array}{r}\text { szórás } \\
2,809\end{array}$} & \multirow{2}{*}{\begin{tabular}{l|} 
átlag \\
11,44
\end{tabular}} & \multirow{2}{*}{\begin{tabular}{c|} 
szórás \\
2,610
\end{tabular}} & \multirow{2}{*}{$\frac{\text { átlag }}{11,62}$} & \multirow{2}{*}{$\begin{array}{l}\text { szórás } \\
2,599\end{array}$} & \\
\hline A tágabb & fiú & & & & & & & & & & & 2,26 \\
\hline közösséghez & lány & 9,67 & 2,376 & 10,48 & 2,203 & 10,59 & 2,534 & 11,23 & 2,663 & 11,37 & 2,747 & 1,70 \\
\hline füződő viszony & össz. & 9,52 & 2,200 & 10,18 & 2,108 & 10,64 & 2,664 & 11,33 & 2,632 & 11,49 & 2,672 & 1,97 \\
\hline \multirow{3}{*}{$\begin{array}{c}\text { Az osztálykohézió } \\
\text { megléte vagy } \\
\text { hiánya }\end{array}$} & fiú & 24,10 & 5,101 & 25,20 & 4,495 & 26,33 & 5,219 & 27,79 & 5,584 & 27,99 & 5,654 & 3,89 \\
\hline & lány & 25,29 & 5,203 & 26,10 & 4,789 & 25,95 & 4,752 & 26,98 & 5,049 & 27,01 & 5,117 & 1,72 \\
\hline & össz. & 24,71 & 5,173 & 25,66 & 4,657 & 26,13 & 4,974 & 27,37 & 5,316 & 27,49 & 5,392 & 2,78 \\
\hline \multirow{3}{*}{$\begin{array}{c}\mathrm{A} \\
\text { diákönkormányzat } \\
\text { szerepe }\end{array}$} & fiú & 28,49 & & & & & & 32 & & 33,17 & 5,801 & 4,68 \\
\hline & lány & 29,76 & 5,538 & 30,08 & 5,302 & 31,45 & 5,371 & 33,03 & 5,409 & 33,14 & 5,397 & 3,38 \\
\hline & össz. & 29,14 & 4,965 & 29,76 & 4,991 & 31,35 & 5,401 & 32,93 & 5,547 & 33,16 & 5,581 & 4,02 \\
\hline \multirow{3}{*}{$\begin{array}{l}\text { A közlemény } \\
\text { funkciója }\end{array}$} & fiú & 29,95 & 4,804 & 31,38 & 4,978 & 35,14 & 7,242 & 37,41 & 6,828 & 37,88 & 6,939 & 7,93 \\
\hline & lány & 31,75 & 6,326 & 32,63 & 6,202 & 34,29 & 6,568 & 36,36 & 6,592 & 36,44 & 6,725 & 4,69 \\
\hline & össz. & 30,88 & 5,694 & 32,02 & 5,659 & 34,70 & 6,897 & 36,87 & 6,709 & 37,14 & 6,849 & 6,26 \\
\hline \multirow{3}{*}{$\begin{array}{l}\text { Az osztályon } \\
\text { belüli társas } \\
\text { kapcsolatok }\end{array}$} & fiú & 2,91 & 1,334 & 2,97 & 1,341 & 3,48 & 1,215 & 4,00 & 0,994 & 3,99 & 1,023 & 1,08 \\
\hline & lány & 3,49 & 1,345 & 3,57 & 1,351 & 3,78 & 1,041 & 3,95 & 0,970 & 3,91 & 0,962 & 0,42 \\
\hline & össz. & 3,21 & 1,368 & 3,28 & 1,376 & 3,63 & 1,136 & 3,97 & 0,980 & 3,95 & 0,990 & 0,74 \\
\hline \multirow{3}{*}{$\begin{array}{l}\text { Közösségi } \\
\text { tevékenység }\end{array}$} & fiú & 25,35 & 4,472 & 26,80 & 5,438 & 30,63 & 6,621 & 32,12 & 5,529 & 32,40 & 5,676 & 7,05 \\
\hline & lány & 27,62 & 5,531 & 28,45 & 5,556 & 31,55 & 6,240 & 34,49 & 5,447 & 34,75 & 5,355 & 7,13 \\
\hline & össz. & 26,51 & 5,157 & 27,65 & 5,545 & 31,10 & 6,426 & 33,34 & 5,600 & 33,60 & 5,623 & 7,09 \\
\hline
\end{tabular}


3. táblázat. A közösség iránti beállitódás átlagai és szórásai a kontrollcsoportokban (Forrás: a Szerzö)

\begin{tabular}{|c|c|c|c|c|c|c|c|c|c|c|c|c|}
\hline \multirow{2}{*}{\multicolumn{2}{|c|}{$\begin{array}{l}\text { Közösség iránti } \\
\text { beállítódás } \\
\text { Kontrollcsoport } \\
\mathrm{N}=177 \\
\text { Fiú: } 83 \text {, Lány: 94) }\end{array}$}} & \multicolumn{2}{|c|}{$\begin{array}{l}\text { 1.mérés } \\
\text { (bemenet) }\end{array}$} & \multicolumn{2}{|c|}{ 2. mérés } & \multicolumn{2}{|c|}{ 3. mérés } & \multicolumn{2}{|c|}{ 4. mérés } & \multicolumn{2}{|c|}{$\begin{array}{l}\text { 5. mérés } \\
\text { (kimenet) }\end{array}$} & \multirow{2}{*}{\begin{tabular}{|l} 
átlagok \\
különb- \\
sége \\
beme- \\
net és \\
kimenet
\end{tabular}} \\
\hline & & \multirow{2}{*}{\begin{tabular}{r|} 
átlag \\
9,70
\end{tabular}} & \multirow{2}{*}{\begin{tabular}{|r|} 
szórás \\
2,463 \\
\end{tabular}} & \multirow{2}{*}{\begin{tabular}{r|} 
átlag \\
9,70 \\
\end{tabular}} & \multirow{2}{*}{$\begin{array}{r}\text { szórás } \\
2,463\end{array}$} & \multirow{2}{*}{$\begin{array}{l}\text { átlag } \\
10,29 \\
\end{array}$} & \multirow{2}{*}{$\begin{array}{r}\text { szórás } \\
2,087\end{array}$} & \multirow{2}{*}{$\begin{array}{l}\text { átlag } \\
10,73 \\
\end{array}$} & \multirow{2}{*}{$\begin{array}{r}\text { szórás } \\
2,333 \\
\end{array}$} & \multirow{2}{*}{\begin{tabular}{|l|} 
átlag \\
11,33 \\
\end{tabular}} & \multirow{2}{*}{\begin{tabular}{|r|} 
szórás \\
2,867
\end{tabular}} & \\
\hline A tágabb & fiú & & & & & & & & & & & 1,63 \\
\hline közösséghez & lány & 10,15 & 2,586 & 10,16 & 2,579 & 10,47 & 2,169 & 10,86 & 2,284 & 10,85 & 2,586 & 0,7 \\
\hline füződő viszony & össz. & 9,94 & 2,532 & 9,94 & 2,529 & 10,38 & 2,127 & 10,80 & 2,301 & 11,07 & 2,724 & 1,13 \\
\hline \multirow{3}{*}{$\begin{array}{c}\text { Az osztálykohézió } \\
\text { megléte vagy } \\
\text { hiánya }\end{array}$} & fiú & 24,75 & 4,770 & 24,76 & & 25,45 & & 26,48 & 5,431 & 27,35 & 5,575 & 2,6 \\
\hline & lány & 25,60 & 5,381 & 25,60 & 5,381 & 25,13 & 4,969 & 25,98 & 4,988 & 27,39 & 5,106 & 1,79 \\
\hline & össz. & 25,20 & 5,107 & 25,20 & & 25,28 & 4,991 & 26,21 & 5,192 & 27,37 & 5,316 & 2,17 \\
\hline \multirow{3}{*}{$\begin{array}{c}\mathrm{A} \\
\begin{array}{c}\text { diákönkormányzat } \\
\text { szerepe }\end{array} \\
\end{array}$} & fiú & 29,55 & 5,147 & 29,59 & 5,182 & 29,81 & 4,794 & 31,52 & 5,023 & 33,14 & 6,049 & 3,59 \\
\hline & lány & 30,66 & 5,371 & 30,66 & 5,371 & 29,87 & 4,643 & 30,68 & 5,004 & 32,76 & 5,081 & 2,1 \\
\hline & össz. & 30,14 & 5,282 & 30,16 & 5,296 & 29,84 & 4,701 & 31,07 & 5,016 & 32,94 & 5,543 & 2,8 \\
\hline \multirow{3}{*}{$\begin{array}{l}\text { A közlemény } \\
\text { funkciója }\end{array}$} & fiú & 32,31 & 6,518 & 32,36 & 6,506 & 32,61 & 6,585 & 34,59 & 7,260 & 37,27 & 7,094 & 4,96 \\
\hline & lány & 33,23 & 6,870 & 33,30 & 6,914 & 32,35 & 6,452 & 33,78 & 6,972 & 36,52 & 6,368 & 3,29 \\
\hline & össz. & 32,80 & 6,704 & 32,86 & 6,723 & 32,47 & 6,497 & 34,16 & 7,100 & 36,87 & 6,709 & 4,07 \\
\hline \multirow{3}{*}{$\begin{array}{l}\text { Az osztályon } \\
\text { belüli társas } \\
\text { kapcsolatok }\end{array}$} & fiú & 3,69 & 1,125 & 3,69 & 1,125 & 3,34 & 1,337 & 3,11 & 1,179 & 3,52 & 1,028 & $-0,17$ \\
\hline & lány & 3,35 & 1,420 & 3,35 & 1,420 & 3,21 & 1,359 & 3,09 & 1,215 & 3,33 & 1,061 & $-0,02$ \\
\hline & össz. & 3,51 & 1,297 & 3,51 & 1,297 & 3,27 & 1,346 & 3,10 & 1,195 & 3,42 & 1,047 & $-0,09$ \\
\hline \multirow{3}{*}{$\begin{array}{l}\text { Közösségi } \\
\text { tevékenység }\end{array}$} & fiú & 29,52 & 5,962 & 29,51 & 5,958 & 29,83 & 4,958 & 31,94 & 6,099 & \begin{tabular}{|l|}
34,51 \\
\end{tabular} & 6,358 & 4,99 \\
\hline & lány & 28,78 & 6,897 & 28,83 & 6,884 & 29,45 & 5,482 & 30,81 & 5,999 & 33,00 & 5,440 & 4,22 \\
\hline & össz. & 29,12 & 6,468 & 29,15 & 6,457 & 29,63 & 5,232 & 31,34 & 6,055 & 33,71 & 5,919 & 4,59 \\
\hline
\end{tabular}

A két csoport átlagainak változását és a nemek közötti különbségeket vizsgáltuk. Többszempontú varianciaanalízissel (VA) került elemzésre az időben egymást követö öt mérés (idő), a kísérleti vagy a kontroll csoportba tartozás, valamint a nem hatása a közösségi beállítódás összetevőire nézve: tágabb közösséghez füződő viszony, osztálykohézió megléte és hiánya, az önkormányzat szerepe, a közlemény funkciója, az osztályon belüli társas kapcsolatok, a közösségi tevékenység. A függő változó a közösség iránti beállítódás területei, a független változók pedig az idő, a csoportok és a nemek.

Varianciaanalízist végeztünk (Type III.): függő változó: tágabb közösséghez füződő viszony, független változók: nem, csoport, idő (ez utóbbi személyen belüli faktor). Szignifikánsnak bizonyult az idő $(\mathrm{F}(4,347)=17.63, \mathrm{p}<0.001$, eta négyzet $=0.17)$, az idö $\mathrm{x}$ csoport interakció $(\mathrm{F}(4,347)=3.03, \mathrm{p}=0.018$, eta négyzet $=0.03)$ és az idő $\mathrm{x}$ nem interakció $((\mathrm{F}(4,347)=2.82, \mathrm{p}=0.025$, eta négyzet $=0.03)$

A 2. ábra mutatja a kísérleti és a kontrollcsoport közötti eltérést a tágabb közösséghez füződő viszony területén. Az összehasonlító grafikon alapján látható, hogy kísérleti és a kontrollcsoport esetében is pozitív változás tapasztalható a négy éves vizsgálat során. Érdekes megfigyelni, hogy a kísérleti csoportnál az 1. bementi mérést követően erőteljes változás tapasztalható. A grafikon a kísérleti csoportnál meredekebb, mint a kontrollcsoportnál.

A kísérleti csoport esetében (post hoc vizsgálat alapján) az 1-4. és 1-5. mérés között szignifikáns a különbség $(\mathrm{p}<0,000)$. A kísérleti és a kontrollcsoport 1 . mérése között nincs szignifikáns $(\mathrm{p}=0,925)$ különbség, tehát a bemeneti mérések a két csoport közel azonos szintről való indulását tanúsítják. 
2. ábra. A kísérleti és kontrollcsoport átlagainak változása az idö függvényében a tágabb közösséghez füzödő viszony esetében (Forrás: a Szerzök)

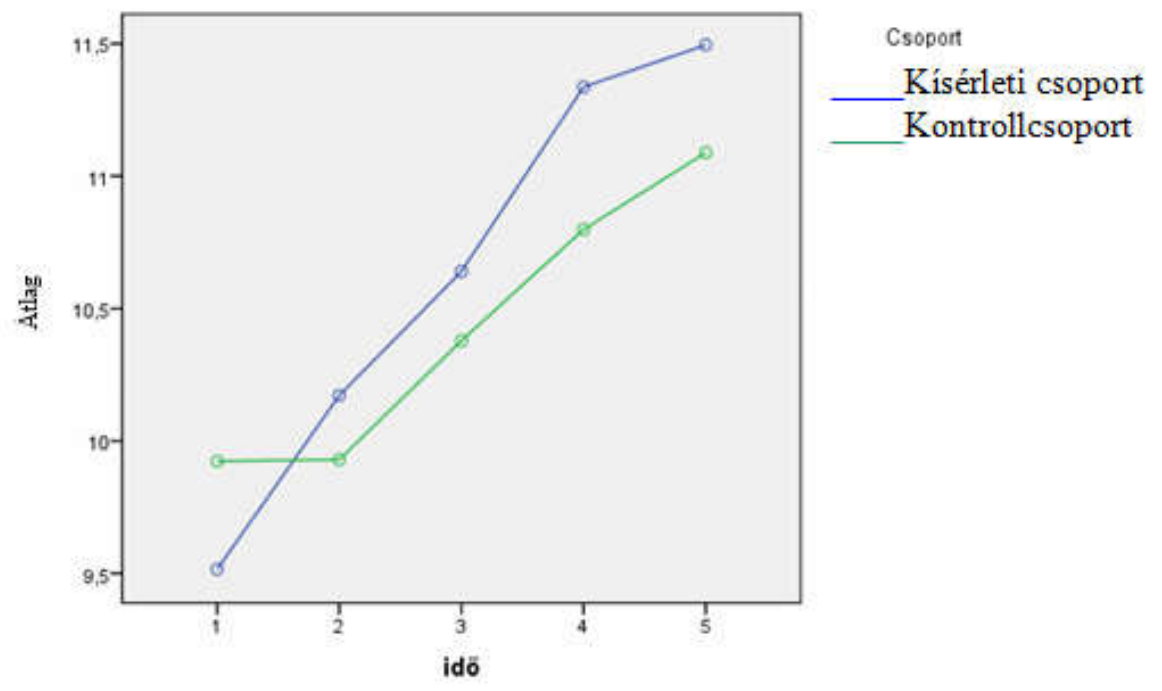

Varianciaanalízist végeztünk (Type III.): függő változó: osztálykohézió, független változók: nem, csoport, idő (ez utóbbi személyen belüli faktor). Szignifikánsnak bizonyult az idő $(F(4,347)=15.41, p<0.001$, eta négyzet $=0.15)$ és az idő $x$ csoport interakció $(F(4,347)=4.28$, $\mathrm{p}=0.002$, eta négyzet $=0.05$ ).

Az 3. ábra mutatja a kísérleti és a kontrollcsoport közötti eltérést az osztálykohézió megléte vagy hiánya területén. A grafikon ábrája alapján látható, hogy bár mind a két csoportnál tapasztalható pozitív irányú növekedés, de ez a kísérleti csoportban erőteljesebben jelenik meg, mint a kontrollcsoport esetében. A kísérleti csoportnál a bementi mérést követően folyamatos emelkedés látható az osztálykohézió megléte területén. A 4. mérés után már egyenletesebb a változás. A kontrollcsoportnál az 1. és 2. mérést követően nincs nagyobb változás, viszont a 3. mérést követően már igen. A grafikon a kísérleti csoportnál meredekebb a 3. mérésig, mint a kontrollcsoportnál.

A kísérleti csoport esetében (post hoc vizsgálat alapján) 1-4. és 1-5 mérés között $(\mathrm{p}<0,05)$ szignifikáns a különbség. A kísérleti és a kontrollcsoport 1. mérése között nincs szignifikáns $(\mathrm{p}=0,997)$ különbség, tehát a két csoport közel azonos szintről indult e területen a bementi méréskor.

Varianciaanalízist végeztünk (Type III.): függő változó: diákönkormányzat, független változók: nem, csoport, idő (ez utóbbi személyen belüli faktor). Szignifikánsnak bizonyult az idő $(\mathrm{F}(4,347)=25.57, \mathrm{p}<0.001$, eta négyzet $=0.23)$ és az idő $\mathrm{x}$ csoport interakció $(\mathrm{F}(4,347)=6.13, \mathrm{p}<0.001$, eta négyzet $=0.07)$.

A 4. ábra mutatja a kísérleti és a kontrollcsoport közötti eltérést a diákönkormányzat szerepe területén. A kísérleti csoportnál a bemeneti mérést követően pozitív változás tapasztalható, ami jobb müködést mutat az iskolai diákönkormányzat életében. Teljesen egyértelmü, hogy ez a változás a 2 . méréstől erőteljesen növekszik, ami szerint 6 . osztálytól jobban bevonódnak a tanulók az önkormányzat életébe. A kontrollcsoportnál a 2. mérést követően hanyatlást mutat a grafikon, majd a 4. mérésnél már emelkedés látható.

A grafikon a kísérleti csoportnál meredekebb, mint a kontrollcsoportnál. A kísérleti csoport esetében az 1-3., 1-4. és 1-5. mérés között $(p<0,05)$ szignifikáns a különbség. A kísérleti és a kontrollcsoport 1. mérésének adatai között nincs szignifikáns különbség $(p=0,738)$, tehát a két 
csoport közel azonos szintröl indult a bementi mérések idején (post hoc vizsgálat alapján). Szignifikáns különbség a 4. mérésnél mutatkozik ( $\mathrm{p}=0,030)$.

3. ábra. A kisérleti és kontrollcsoport átlagainak változása az idő függvényében az osztálykohézió megléte vagy hiánya esetében (Forrás: a Szerzők)

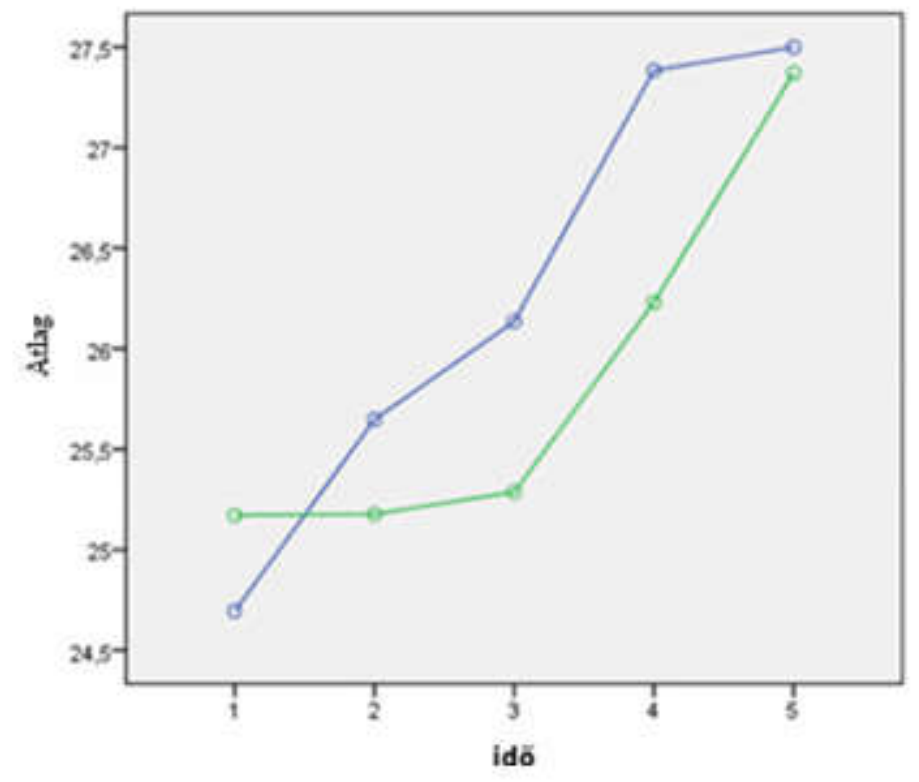

Csoport

Kisérleti csoport

Kontrollcsoport

4. ábra. A kísérleti és kontrollcsoport átlagainak változása az idö függvényében a diákönkormányzat szerepe esetében (Forrás: a Szerzök)

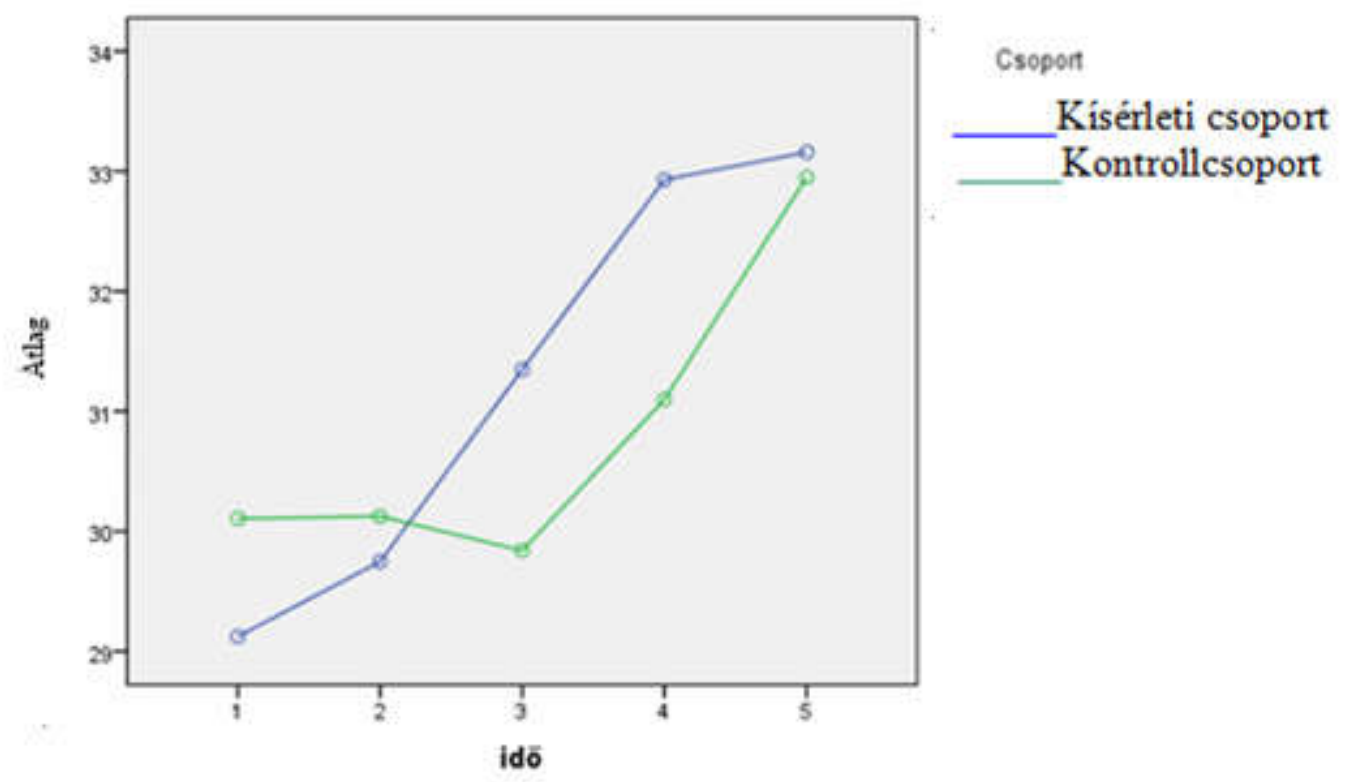


Varianciaanalízist végeztünk (Type III.): függő változó: közlemény funkciója, független változók: nem, csoport, idő (ez utóbbi személyen belüli faktor). Szignifikánsnak bizonyult az idő $(\mathrm{F}(4,347)=41.56, \mathrm{p}<0.001$, eta négyzet $=0.32)$ és az idő $\mathrm{x}$ csoport interakció $(\mathrm{F}(4,347)=9,45, \mathrm{p}<0.001$, eta négyzet $=0.098)$.

Az 5. ábra a kísérleti és a kontrollcsoport közötti eltérést mutatja a közlemény funkciója területén. A kísérleti csoportnál a 2. mérést követően meredeken emelkedik a grafikon vonala, ami erőteljes fejlődést mutat a közlemény funkciójának esetében. A folyamatos és erőteljes növekedés után a 4. mérésnél már egyenletesebb lesz a grafikon vonala. A kontrollcsoport esetében a 2. mérés után csökkenés látható, majd a 3. méréstől folyamatos növekedés látszik. A grafikon a kísérleti csoportnál meredekebb, mint a kontrollcsoportnál.

A kísérleti csoport esetében az 1-3., 1-4. és 1-5. mérés között szignifikáns a különbség $(\mathrm{p}<0,05)$, a 2-3. mérés között szintén szignifikáns $(\mathrm{p}=0,005)$ a különbség. A kísérleti és a kontrollcsoport 1. mérése között nincs szignifikáns $(\mathrm{p}=0,152)$ különbség, tehát a két csoport közel azonos szintről indult a bementi mérések idején. Itt a 3. és a 4 mérések között van szignifikáns $(p<0,05)$ különbség (post hoc vizsgálat alapján).

5. ábra. A kisérleti és kontrollcsoport átlagainak változása az idö függvényében a közlemény funkciója esetében (Forrás: a Szerzök)

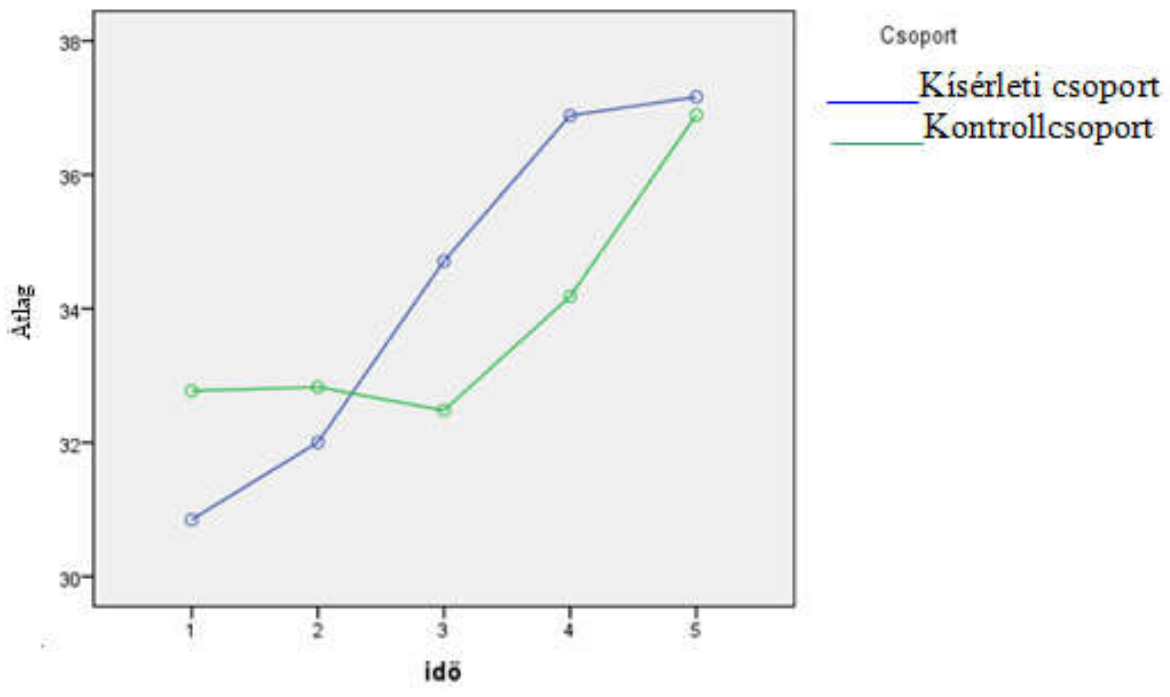

Varianciaanalízist végeztünk (Type III.): függő változó: osztályon belüli társas kapcsolatok, független változók: nem, csoport, idő (ez utóbbi személyen belüli faktor). Szignifikánsnak bizonyult az idő $(\mathrm{F}(4,347)=17.05, \mathrm{p}<0.001$, eta négyzet $=0.16)$, az idő $\mathrm{x}$ csoport interakció $(\mathrm{F}(4,347)=10.41, \mathrm{p}<0.001$, eta négyzet $=0.11)$ és az idő $\mathrm{x}$ csoport $\mathrm{x}$ nem interakció $(\mathrm{F}(4,347)=2.60, \mathrm{p}=0.036$, eta négyzet $=0.03)$.

A 6. ábra mutatja a kísérleti és a kontrollcsoport közötti eltérést az osztályon belüli társas kapcsolatok területén. A kísérleti csoportnál a 2. mérést követően meredeken emelkedik a grafikon vonala, ami erőteljes fejlődést mutat az osztályon belüli társas kapcsolatok esetében. A 4. mérést követően ez a folyamat megáll. A kontrollcsoport esetében a 2. mérés után csökkenést láthatunk, majd a 4. méréstöl növekedés látható az eredményekben. A grafikon a kísérleti csoportnál jóval meredekebb, mint a kontrollcsoportnál.

A kísérleti csoport esetében (post hoc vizsgálat alapján) az 1-3., 1-4. és 1-5. mérés között $(\mathrm{p}<0,05)$ szignifikáns a különbség. A kísérleti és a kontrollcsoport 1. mérése között nincs 
szignifikáns $(\mathrm{p}=0,385)$ különbség, tehát a két csoport közel azonos szintről indult a bementi mérések idején. Szignifikáns különbség a 4. mérések között van ( $\mathrm{p}=0,002)$.

6. ábra. A kísérleti és kontrollcsoport átlagainak változása az idö függvényében az osztályon belüli társas kapcsolatok esetében (Forrás: a Szerzök)

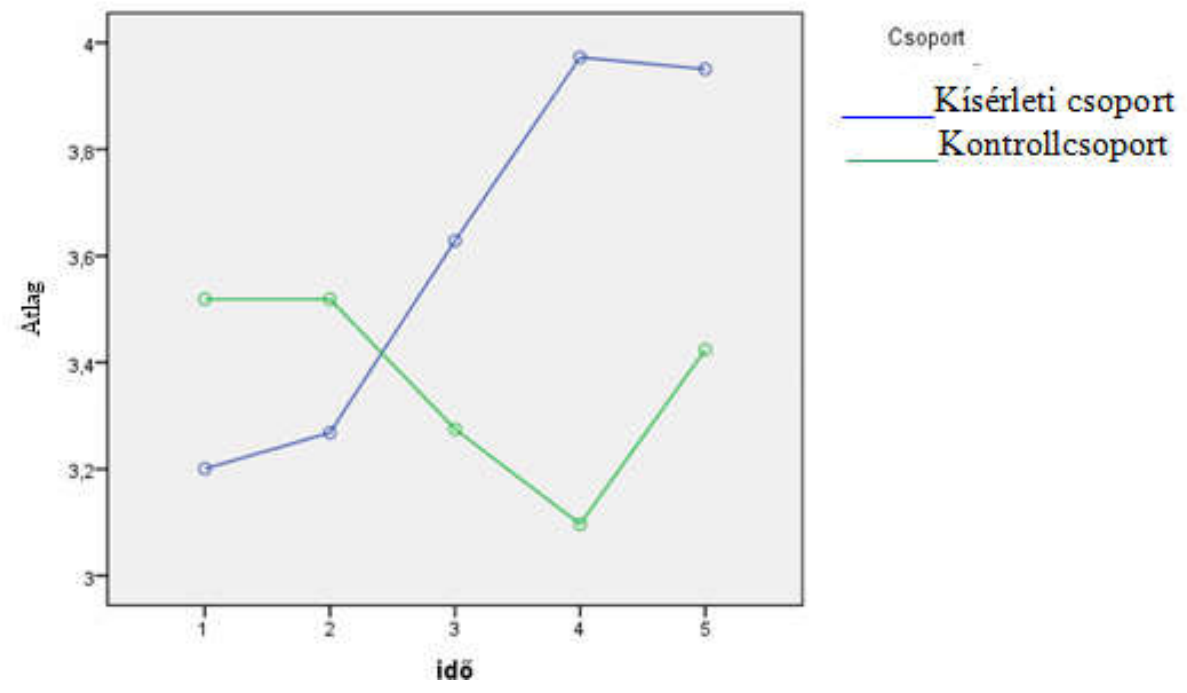

Varianciaanalízist végeztünk (Type III.): függő változó: közösségi tevékenység, független változók: nem, csoport, idő (ez utóbbi személyen belüli faktor). Szignifikánsnak bizonyult az idő $(\mathrm{F}(4,347)=58.06, \mathrm{p}<0.001$, eta négyzet $=0.40)$ és az idő $\mathrm{x}$ csoport interakció $(\mathrm{F}(4,347)=12,77, \mathrm{p}<0.001$, eta négyzet $=0.13)$.

A 7. ábra mutatja a kísérleti és a kontrollcsoport közötti eltérést a közösségi tevékenység területén. A kísérleti csoportnál a 2. mérést követően meredeken emelkedik a grafikon vonala, ami pozitív irányt mutat a közösségi tevékenység esetében. A folyamatos emelkedés után a 4. mérést követően alig van változás. A kontrollcsoport esetében a 2. mérés után lassú emelkedés látható, majd a 3. méréstől aktívabb változás tapasztalható. A grafikon meredeksége a kísérleti csoportnál és a kontrollcsoportnál hasonló változást mutat.

A kísérleti csoport esetében az 1-3., 1-4. és 1-5. mérés között $(\mathrm{p}<0,05)$ szignifikáns a különbség. A kísérleti csoport 2-3., 3-4. mérésénél szintén szignifikáns $(p<0,05)$ különbség van. A kísérleti és a kontrollcsoport 1 . mérése között van szignifikáns $(p=0,002)$ különbség, ami azt jelenti, hogy a kísérleti csoport tanulói e területen számottevő hátránnyal indulnak. Ezt a számottevő hátrányt később aztán behozzák, sőt a 4. mérések idején nemcsak hogy megfordul a viszony, hanem a különbség szignifikánssá $(p=0,008)$ is válik a kísérleti csoport javára. Érdekes ugyanakkor, hogy az utolsó méréskor (8. évfolyam) a két csoport eredményei csaknem egybeesnek (post hoc vizsgálat alapján). 
7. ábra. A kísérleti és kontrollcsoport átlagainak változása az idö függvényében a közösségi tevékenység esetében (Forrás: a Szerzök)

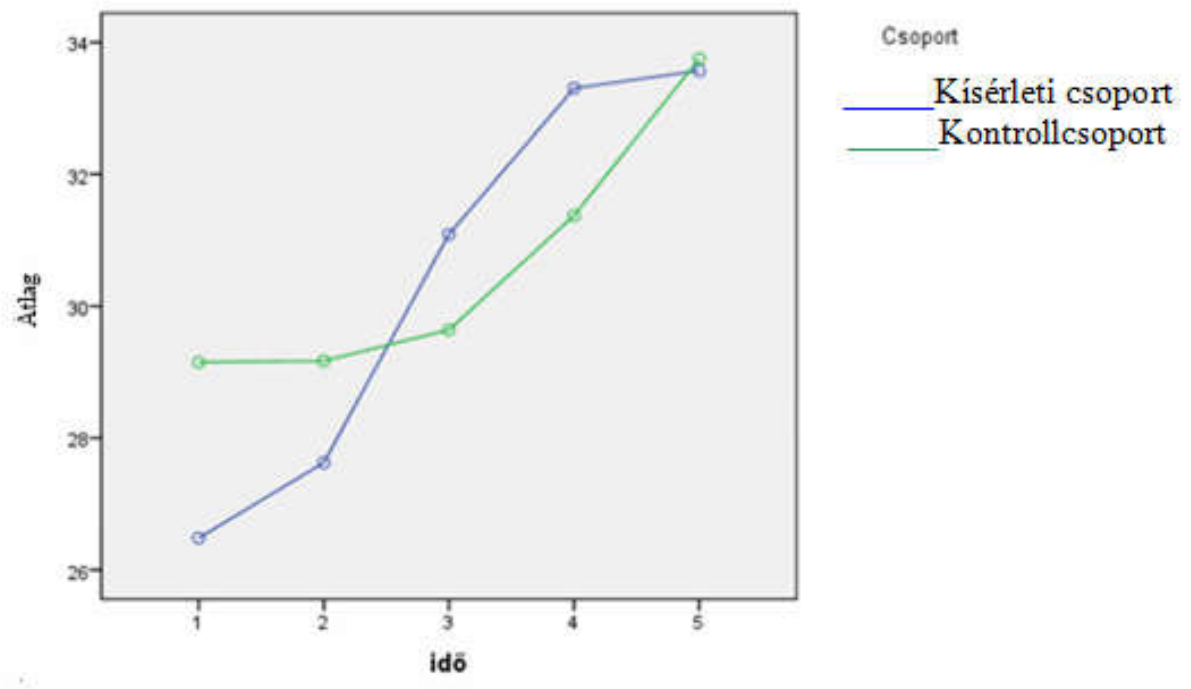

\section{Megvitatás és korlátok}

Ha összehasonlítjuk a kísérleti és kontrollcsoport bemeneti és kimeneti átlagai közötti különbséget, azt látjuk, hogy pontszámban kifejezve az eltérések nem nagyok. A „szignifikáns különbség” csupán annyit jelent, hogy a különbség nem a véletlen müve. Megtévesztő lehet a bemutatott ábráknál, hogy az ábrázolás korlátai miatt az egyes ábrák kordináta tengelyeinek beosztása nem egyforma. Így az ábrákat nézve számos esetben a különbségek sokkal nagyobbnak tủnnek, mint amilyenek valójában.

Hipotézisünk csak részben teljesült. Feltételeztük, hogy a felső tagozatos tanulók közösség iránti beállítódásának a fejlődése a folyamatos differenciálás hatására a kísérleti csoportnál hamarabb indul meg és ez hatékonyabb lesz, mint a kontrollcsoportnál. A hipotézisünk azon része, hogy hamarabb bekövetkezik a kísérleti csoportnál a fejlődés, beigazolódni látszik, ezt a varianciaanalízis során a csoport x idő interakció támasztja alá. A közösség iránti beállítódás mindegyik területére vonatkozóan azt vártuk, hogy a négy éves időtartam alatt jelentős és folyamatosan növekvő különbség lesz a kísérleti csoport javára, viszont ez nem támasztódott alá. Azokon a területeken, amelyeknél szignifikáns különbség $(\mathrm{p}<0,05)$ mutatkozott a kísérleti csoport javára, az átlagpontszámbeli különbségek kicsik voltak. Ez arra utal, hogy bár a differenciált oktatás hatása egyes területekre vonatkozóan tagadhatatlan, de nem jelent akkora hatást, mint amire számítottunk. Természetesen az idő elteltével a kontrollcsoport tanulói között is kialakult az osztálykohézió.

Elviekben tudjuk, hogy azoknál a csoportoknál, ahol az osztályon belüli társas kapcsolatok magas szintet mutatnak, a tanulók megfelelően tudnak együttmüködni, kevés a peremhelyzetben lévő gyermek, az osztály és az iskola életében is aktívan részt vállalnak. Józsa (2004) kutatásához hasonlóan vizsgálatunkban is azt tapasztaltuk, hogy a család és az iskola, az osztályközösség meghatározó az egyén szocializációjában és elfogadás érzésének kialakításában. Tekintve, hogy osztálybeli társas kapcsolatokról van szó, amelyeknek személyesen részesei a tanulók, továbbá ezek a tanulók végig egy osztályba jártak az ötödiktől a nyolcadik osztályig, nehezen képzelhető el, hogy a belső kapcsolatokat a tanulók 8. osztályos korukban ugyanolyannak véleményezték, mint amikor 5. osztályba jártak. Szerintünk inkább az történhetett, hogy a tanulók az osztálybeli kapcsolataikat úgy élték meg, mint amelyeknek ők is részesei, és erről nem akartak felelősen nyilatkozni más (a vizsgálatot 
végző, többnyire idegen személy) előtt. Vajda (2002) megfigyelése alátámasztja a vizsgálatunk azon részét, hogy a tanulók eredményesebbek az együttes tevékenységeikben, fejlődik az önértékelésük és a kommunikációjuk. Józsa és Fejes (2012) kutatásai szintén hasonló eredményekre jutottak, miszerint a diákok szubjektív jóléte hatással van az iskolához és a társakhoz való viszony pozitív irányú változására.

\section{KÖVETKEZTETÉSEK}

Jelen tanulmányban az iskolai differenciált oktatás személyiségre gyakorolt hatásának nagyobb ívű vizsgálatából a közösség iránti beállítódás mérésének eredményeit mutattuk be. A differenciálás, vagyis az „egyéni bánásmód” szükségét régóta hangoztatja a pedagógia, ennek köszönhetően nagyon sok elmélet, módszer született, de mind a mai napig nagyon nehéz kérdés a gyakorlatban a differenciálás megvalósítása, mivel az adott osztályokba járó tanulók között nagyon nagy eltérések tapasztalhatóak, akár mentális, akár képességbeli különbségek alapján. Varga Tamás 1971-ben végzett vizsgálatában megállapította, hogy a mentális fejlettség alapján 100 gyermek közül csak 26 járhatna 4. osztályba, a többi gyermeket 1-3. illetve 5-8. osztályba lehetne besorolni (Fehér Irén, 2001; in: Lappints Árpád, pp. 310.).

A pedagógusok differenciálásról alkotott képe egyre inkább formálódik az ismeretek és a gyakorlati tapasztalatok hatására. Ezt mutatja Petriné és munkatársai újabb kutatása. Az értékelés alapján elmondható, hogy a pedagógusok egyre több ismerettel rendelkeznek a gyermek megismerésével és az egyéni bánásmóddal kapcsolatban, de ezeket „leegyszerüsítve” alkalmazzák a gyakorlatban és sok esetben még mindig ellentmondásosan viszonyulnak a differenciáláshoz (Petriné, 2001). Tapasztalatunk szerint ez ma is így van.

Az általunk végzett kutatás éppen arra kívánt rámutatni, hogy a tanulók fejlődésében, ezen belül a közösség iránti beállítódásban meghatározó lehet a differenciálás.

Hipotézisünk szerint a felső tagozatos tanulók közösségi iránti beállítódásának a fejlődése a folyamatos differenciálás hatására a kísérleti csoportnál hamarabb indul meg, és ez hatékonyabb, mint a kontrollcsoportnál. A közösség iránti beállítódásnak a Hunyadyné (1977) által leírt hat összetevőjét vizsgálva azt tapasztaltuk, hogy a hat összetevő közül háromnak az esetében - a tágabb közösséghez füződő viszony, a közösségi tevékenység és az osztálykohézió fejlődése - a tervezett és tudatos differenciálás számottevően nagyobb változást eredményezett a kísérleti csoportban. Azonban az önkormányzat szerepe és a közlemény funkciója területe mind a két csoportnál hasonlóan alakult, azaz csekély különbség volt tapasztalható a négy év során. Az osztályon belüli társas kapcsolatok terén pedig gyakorlatilag nem volt változás. Mivel a differenciálás hatása itt nem bizonyult számottevőnek, úgy tünik, hogy utóbbi három terület közül kettő fejlődésében nagyobb szerepe van az életkornak, a harmadiknál pedig egyiknek sem, hiszen ennél a négy év alatt nem történt változás.

A kutatásnak és az eredmények értelmezési korlátait a következőkben látjuk: 1) A vizsgálati minta nem volt reprezentatív, jóllehet ügyeltünk arra, hogy a bevont tanulók különféle típusú települések iskoláiból kerüljenek ki. 2) Nem állt módunkban más, hasonló kutatásokkal összevetni az eredményeket, mivel ilyeneket nem sikerült fellelni a nemzetközi szakirodalomban. Egyedül Hunyadyné (1977) vizsgálatát hivatkozhatjuk le, amellyel összhangban mi is azt találtuk, hogy ,,a közösségi beállítódás az évek során hullámzik, és az érés folyamatának nyomait is magán viseli” (Hunyadyné, 1977, pp. 165.). Ugyanakkor érdemes megemlíteni, hogy Hunyadyné kutatásával ellentétben a mi kutatásunk egyfajta hatásvizsgálatnak fogható fel, továbbá longitudinális jellegü volt, így a változásokat pontosan nyomon lehetett követni. 3) Nem volt minden szempontból biztosítható az, hogy a kísérleti és a kontrollcsoport tanulói csakis egyetlen szempontból különbözzenek, nevezetesen abban, hogy részesülnek-e a négy év során rendszeres differenciált oktatásban vagy nem. 
Hozzátesszük, ezt nem is tartjuk lehetségesnek. 4) Nem vizsgáltuk az egyes alskálák reliabilitását, hanem azt létezőnek vettük. Hunyadyné könyvének átnézésekor derült ki, hogy ilyen vizsgálatot Hunyadyné sem végzett, az egyes területek egy előzetes vizsgálatban kapott tanulói válaszok gyakorisága alapján kerültek kialakításra. Úgy gondoljuk, ezt a hiányt a jövőben mindenképpen pótolni kell.

Összességében elmondható, hogy a tervezett, tudatos és jól felépített differenciált fejlesztés a közösség iránti beállítódás néhány területén a kísérleti csoportban pozitívabb változást eredményezett, mint a kontrollcsoportban. Azonban ez közel sem minden terület, mint ahogy azt a hipotézis megfogalmazásakor feltételeztük, továbbá a kimutatott számottevő változások a nagyságrendet tekintve viszonylag csekélyek. Mindebböl arra következtetünk, hogy az életkori jellemzők a csoport hovatartozást több esetben „felülírják”, azaz jobban érvényesülnek, mint az, hogy a tanulók differenciált fejlesztésben részesülnek, vagy nem.

\section{IRODALOM}

Báthory, Z. (1985). Tanitás és tanulás. Tankönyvkiadó, Budapest.

Benda, J. (2002). A kooperatív pedagógia szocializációs sikerei és lehetőségei Magyarországon I. Új Pedagógiai Szemle, 52. (9), 26-37.

Cole, M. és Cole, S. R. (2002). Fejlödéslélektan. Osiris Kiadó, Budapest.

Currie, C., Zanotti, C., Morgan, A., Currie, D., De Looze, M., Roberts, C., Samdal, O., Smith, O., \& Barnekow, V. (2012). Social determinants of health and well-being among young people. Health Behaviour in School-aged Children (HBSC) study. international report from the 2009/2010 survey. Copenhagen. WHO Regional Office for Europe (Health Policy for Children and Adolescents, No. 6).

Csapó, B. (2003). A képességek fejlődése és iskolai fejlesztése. Akadémiai Kiadó, Budapest.

Dai, D. Y. and Sternberg, R. J. (eds.) (2004). Motivation, emotion, and cognition. Integrative perspectives on intellectual functioning and development. Lawrence Erlbaum Associates, Inc. Publishers, Mahwah, NJ.

Eyre, D. and Fuller, M. (1993). Year 6 Teachers and More Able Pupils. Oxford, National Primary Centre.

Fehér, I. (szerk.) (2001). Pedagógia és pszichológia. Comenius, Pécs.

Festinger, L. (1976). A társadalmi összehasonlítás folyamatainak elmélete. In Pataki Ferenc (szerk.). Pedagógiai szociálpszichológia. Gondolat, Budapest. 259-291.

Fülöp, M. (1995). A versengésre vonatkozó tudományos nézetek. Pszichológia, 4. sz. 434474.

Fülöp, M. (2000). A versengés mint szociális képesség. In. Csapó, B., Vidákovics, T. (szerk.). Neveléstudomány az ezredfordulón. Nemzeti Tankönyvkiadó, Budapest, 133-146.

Good, T .L. and Brophy, J. E. (2008). Looking in classroom. Allyn \& Bacon, Boston.

Hattie, J. (2008). Visible Learning - A synthesis of over 800 meta-analyses relating to achievement. Routledge, New York

Hidi, S. and Harackiewicz, J. M. (2000). Motivating the academically unmotivated. A critical issue for the 21th century. Review of Educational Research. 70. 2. sz. 151-179.

Hunyady, Gy. (1977). Kollektivitás az iskolai osztályokban. Akadémiai Kiadó, Budapest.

Józsa, K. (2004). Az első osztályos tanulók elemi alapkészségeinek fejlettsége - Egy longitudinális kutatás első mérési pontja. Iskolakultúra, 14 (11), 3-16.

Józsa K. és Fejes J. B. (2012). A tanulás affektív tényezői. In. Csapó, B. (szerk.). Mérlegen a magyar iskola. Tankönyvkiadó, Budapest. 367-406.

Józsa K. és Székely Gy. (2004). Kisérlet a kooperatív tanulás alkalmazására a matematika tanitása során. Magyar Pedagógia, 104. 3. sz. 339-362. 
Kulcsár, É. (2004). A serdülőkori fejlődés pszichológiai jellemzöi. Iskolapszichológia, 29. ELTE PPK Tanárképzési és - továbbképzési Központ 1-76.

Linnenbrink, E. A. (2004). Person and context. Theoretical and practical concerns in achievement goal theory. In. Pintrich, P. R. és Maehr, M. L. (eds.). Advances in motivation and achievement. Motivating students, improving schools. The legacy of Carol Midgley. Elsevier, Stanford. 159-184.

Marsh, H. W. and Craven R. (2002). The Pivotal Role of Frames of Reference in Academic Self-concept Formation. The Big Fish Little Pond Effect. In. Pajares, F. and Urdan, T. (eds.). Adolescence and Education, Volume 2. Information Age Publishing, Greenwich. 83-123.

Martonné T. M. és N. Kollár K. (2001). A tanulók életmódjának kérdöíves vizsgálata. Iskolapszichológia 25. Budapest

Mikulas, W. L. and Vodanovich, S. J. (1993). The essence of boredom. The Psychological Record, 43. 1. sz. 3-12.

Murayama, K. and Elliot, A. J. (2009). The joint influence of personal achievement goals and classroom goal structures on achievement-related outcomes. Journal of Educational Psychology, 101. 2. sz. 432-447.

Murányi-Kovács E. (1980) A serdülökor (10-16 év). Szülőknek- nevelésröl. Kossuth Könyvkiadó

Nagy, J. és Zsolnai, A. (2001). Szociális kompetencia és nevelés. In. Falus, I. (szerk.). Tanulmányok a neveléstudomány köréböl. Osiris Kiadó, Budapest.

N. Kollár, K. és Szabó, É. (2004). Pszichológia pedagógusoknak. Osiris Kiadó, Budapest

Petriné Feyér, J. (2001). Pedagógusok a differenciálásról. In. Golnhofer, E., Nahalka, I. (szerk.). A pedagógusok pedagógiája. Nemzeti Tankönyvkiadó, Budapest. 221.

Polonkai, M. (2002). Differenciálás a tanulásszervezésben. In. Balogh, L., Koncz, I. és Tóth, L. (szerk). Pedagógiai pszichológia a tanárképzésben. Fitt Image-Debreceni Egyetem, Pedagógiai-pszichológiai Tanszék Szentendre

Schutz, P. A. and Pekrunp, R. (eds., 2007). Emotion in education. Academic Press, San Diego, CA.

Rheinberg, F. (1999). „Trainings auf der Basis eines kognitiven Motivationsmodells” in F. Rheinberg and S. Krug (eds.),Motivationsförderung im Schulalltag, Hogrefe, Göttingen, 2, pp. 36-52.

Szekszárdi, Fné (1992). Helyzetelemzés és folyamatkövetés. In. Az osztálytükörtöl a falfirkákig. Módszerek nemcsak osztályfönököknek. Szerk.. Szabó I., Szekszárdi F. IFAOKI IFK, (ALTERN sorozat).

Tóth, L. (2005). Pszichológiai vizsgálati módszerek a tanulók megismeréséhez. Pedellus Tankönyvkiadó, Debrecen.

Triplett, N. (1987). The dynamogenic factors in pace making and competition. American Journal of Psychology, 9, 507-533.

Vajda, Zs. (2002). A társas kapcsolatok és viselkedés fejlődése kisiskolás kortól serdülőkorig. In. Mészáros Aranka (szerk.). Az iskolai szociálpszichológiai jelenségvilága. ELTE Eötvös Kiadó, Budapest.

Wall, K. (2008). Understanding metacognition through the use of pupils views templates. Pupil views of Learning to Learn. Thinking Skills and Creativity, 3. 1. sz. 23-33.

Wedder-Weiss, D. and Fortus, D. (2012). Adolescents' declining motivation to learn science. A follow-up study. Journal of Research in Science Teaching 49 (9), 1057-1095.

Zsolnai, A. (2003) (szerk.). Szociális kompetencia - társas viselkedés. Gondolat Kiadó, Budapest.

Internetes forrás. 
Kouros, C., Abrami, P. C. (2006). Attitudes toward Small Group Learning. Centre for the Study of Learning and Performance. Concordia University, Montreal, Canada, (Letöltve. 2015. 03. 17.). (Web: www.doe.concordia.ca/cslp/Downloads/PDF/SAGE2006Fi).

\section{MELLÉKLET}

\section{Közösség iránti beállítódás kérdőív}

Az állitások csoportositása jelleg szerint:

- Pozitív állítások: 1,10,12,14,15,16,20,23,26,30,34,37,40

- Negatív állítások: 2,3,5,6,7,9,11,13,17,19,22,24,25,27,28,31,33,35,38,39,

- Túlzó állítások: 4,8,18,21,29,32,36

Az állitások csoportositása tartalom szerint:

- A tágabb közösséghez füződő viszony: $1,8,40$

- Az osztálykohézió megléte vagy hiánya: 4,6,13,20,28,29,30,37

- Az önkormányzat szerepe: 9, 17, 18, 27, 31, 32, 36, 38, 39

- A közvélemény funkciója: 7,10,12,15,19,20,23,24,33,34

- Az osztályon belüli társas kapcsolatok: 35

- Közösségi tevékenység: 2,3,5,11,14,16,22,25,26

Név: Osztály: Dátum:.

Instrukció: Olvasd el a lapon lévő mondatokat! Mindegyik mellett jelöld ki 5-től 1-ig egy-egy számmal, mennyire értesz vele egyet! Hat teljesen egyetértesz, az 5-öst karikázd be; ha inkább egyetértesz, mint nem, a 4-est; ha nem tudod, a 3-ast; ha inkább nem értesz vele egyet, mint igen, a 2-est; ha egyáltalán nem értesz vele egyet, az 1-est.

1. Csak közösségben tudom elképzelni az életemet.

2. Az a fontos, hogy ki mennyit dolgozik, s nem az, hogy miért.

3. Mindenki törődjön a maga dolgával.

4. Minden áron el kell érni, hogy egység legyen az osztályban.

5. Az a jó közösségi gyerek, aki jól tanul.

6. Természetes, hogy a fiúk és a lányok mindig sokat veszekednek.

7. A legjobb minden diák önkormányzati gyülésen hallgatni, abból nem lehet baj.

8. Csak az a fontos, hogy a mi osztályunk legyen az első minden munkában.

9. Senkinek semmi köze hozzá, hogy mit csinálok szabad időmben.

10. A többség döntése mindenkor kötelezö rám.

11. A tanulás minden gyerek saját ügye, a szüleinkívül senkinek nincs köze hozzá. 54321

12. Mindig nyíltan, az osztály előtt kell megmondanunk véleményünket az osztálytársaink viselkedéséről.

13. Ha azt akarjuk, hogy erösebb legyen az osztályközösség, akkor elnézőbbnek kell lennünk egymás hibáival, gyengeségeivel szemben.

14. Az osztályban politikai témáról is kell beszélni.

15. Az osztály életének eseményeit meg kell közösen tárgyalni.

16. A tanulás is közösségi munka, mint a hulladékgyüjtés. 
17. A felelösök csak a tanároknak tartoznak beszámolni.

18. Az osztályban mindenkit egyformán kell becsülni.

19. Az osztályfőnöki órákon és diák önkormányzati gyüléseken üres időtöltés a megbeszélés és vita.

20. Akkor is az osztály érdeke szerint kell cselekednem, ha az számomra kellemetlen.

21. A rendbontó fiúkkal vagy lányokkal addig nem kell szóba állni, amíg meg nem javulnak.

22. A közösség vezetöinek csak szervezni kell a munkát, ők természetesen nem vesznek részt benne.

23. Az osztály közös szokásaihoz mindenkinek alkalmazkodnia kell, ha nem is tetszenek azok valakinek.

24. Bármit mondanak is a többiek, mindenki tartson ki véleménye mellett.

25. Semmi értelme faliújságot készíteni, úgysem olvassa senki.

26. Nagyon jellemző mindenkire, hogy mennyire veszi ki részét az osztály közös munkájából.

27. A diákönkormányzat határozatai csak az iskolában érvényesek, az iskolán kívül nem.

28. A jó osztályközösségben nem jelentik a tanároknak, hogy kik szoktak leckét másolni.

29. Az osztályközösséget úgy kell erősíteni, ha játék helyett is a tankönyveket forgatják a gyerekek.

30. Ha összefog az osztály, meg tudja javítani a legrosszabb gyereket is.

31. Teljesen mindegy, hogy kik a diákvezetők.

32. Felnőttek nélkül is el tudunk végezni minden közösségi munkát.

33. Csak annak a gyereknek engedelmeskedem, akit a választáskor én is megszavaztam.

34. Minden gyereknek kötelessége, hogy elmondja véleményét az osztály ügyeiröl.

35. Ha valaki okosabb, mint társai, s lenézi őket, attól még lehet jó közösségi gyerek.

36. A diákvezetőnek joga van bármit megparancsolni a többieknek.

37. Az osztály érdekében mindent meg kell tennünk.

38. Az osztályban csak a tanárok büntethetnek meg valamiért egy gyereket.

39. Az a jó, ha az osztályban minden feladatot ugyanazok a gyerekek szerveznek meg, mert ők már értenek hozzá.

40. Ahhoz, hogy az osztályunk jó közösség legyen, segíteni kell a többi osztályt is. 